\title{
Managing Biodiversity in Areas Beyond National Jurisdiction
}

\author{
Erik J. Molenaar* \\ Senior Research Associate, Netherlands Institute for \\ the Law of the Sea (NILOS), Utrecht University, \\ Netherlands and Associate Professor, Faculty of Law, \\ University of Tromsø, Norway.
}

\begin{abstract}
The global loss of biological diversity (biodiversity), both terrestrial and marine, occurs currently at an alarming and probably unprecedented rate. The main purpose of this article - which focuses in particular on marine capture fisheries - is to identify shortcomings in the international legal framework relating to the conservation and sustainable use of marine biodiversity in areas beyond national jurisdiction (ABNJ) and possible solutions for selected shortcomings. The latter relate to discrete high seas fish stocks, deep-sea species and fisheries, integrated marine protected areas (MPAs) in ABNJ and, finally, to existing and new rights to conserve marine biodiversity. The main argument on this last topic is that in view of the current rate loss of marine biodiversity, reform should not just be limited to the traditional approach of strengthening, deepening and broadening obligations but should be balanced with optimizing use of existing rights and/or granting new rights to ensure that the overarching balance between socio-economic interests and the interests of marine biodiversity of present and future generations is archived.
\end{abstract}

\section{Introduction}

The global loss of biological diversity (biodiversity), both terrestrial and marine, currently occurs at an alarming and probably unprecedented rate. There are various causes of this loss, but there is little doubt that human activities are, directly or indirectly, the main cause. While loss of biodiversity is already deplorable philosophically, biodiversity is also valuable to humans for other reasons, for instance for exploitation purposes, as a source for biotechnology,

* The author is grateful for comments by H. Nieuwenhuis and A. Trouwborst on an earlier version, which will be published as E.J. Molenaar, "Managing Biodiversity in Areas Beyond National Jurisdiction," in T. Heidar, R. Long and J.N. Moore (eds) Law, Science and Ocean Management (Martinus Nijhoff Publishers: 2007 forthcoming). However, the author remains responsible for the current text. The author can be contacted at E.Molenaar@law.uu.nl.

THE INTERNATIONAL JOURNAL OF MARINE AND COASTAL LAW, Vol 22, No 1

(C) Koninklijke Brill NV, 2007 
for the ecosystem services that it provides, as a basis for tourism, for cultural or spiritual reasons, or simply for the mere knowledge of its existence. ${ }^{1}$

Marine biodiversity is affected by human activities on land, in the coastal zone and further offshore. The following main human activities may or do occur in (marine) areas beyond national jurisdiction (ABNJ; a term that is clarified further below): marine capture fisheries, navigation, marine scientific research, ${ }^{2}$ bioprospecting, ${ }^{3}$ laying submarine cables and pipelines, constructing artificial islands and other installations, ocean dumping, exploration and exploitation of non-living resources, and overflight. ${ }^{4}$ But human activities on land and in the coastal zone affect marine biodiversity in ABNJ as well. For instance, the impact of land-based pollution, including pollution through the atmosphere, is likely to gradually increase and spread further offshore. Seamounts, cold-water coral reefs, hydrothermal vents and sponge fields are often mentioned as features in $\mathrm{ABNJ}$ that are under particular threat from human activities that take place in those areas. ${ }^{5}$

This article has a strong focus on marine capture fisheries, which currently may well be the largest threat to, or have the most impact on, marine biodiversity in ABNJ. ${ }^{6}$ This is due to over-exploitation of many target species (including discards), impacts on the broader marine ecosystem as a consequence of by-catch of non-target species (e.g., fish, sedentary species, megafauna and birds) and impacts on the benthos. Assessing the relative threat to, or impact on, marine biodiversity in ABNJ of various human activities, wherever they take place, is an almost impossible task. And even if it were feasible, the ensuing prioritization for remedial action is very likely to be significantly influenced by a cost-benefit analysis in which juridical and political considerations take a prominent place. In this light, it is noteworthy that the impacts of marine capture fisheries are much more tangible to a broader public, than, for instance,

1 See the first two preambular paragraphs to the CBD (Convention on Biological Diversity, Nairobi, 22 May 1992. In force 29 December 1993, 31 International Legal Materials 822 (1992); <www.biodiv.org >).

2 It should be noted that the LOS Convention (United Nations Convention on the Law of the Sea, Montego Bay, 10 December 1982. In force 16 November 1994, 1833 United Nations Treaty Series 396; <www.un.org/Depts/los>) does not contain a definition for marine scientific research. Accordingly, while some States do not regard activities like routine hydrographic surveys as marine scientific research, others do.

3 Bioprospecting is regarded by some as marine scientific research. See also the discussion by M.W. Lodge, "Improving International Governance in the Deep Sea," 19 International Journal of Marine and Coastal Law 299-316 (2004), at p. 302, n. 13.

4 K.M. Gjerde, "Ecosystems and Biodiversity in Deep Waters and High Seas," UNEP Regional Seas Reports and Studies No. 178 (2006; available at <www.unep.org $>$ ), at pp. 31-32 also mentions various options to store $\mathrm{CO}_{2}$ in the water column or beneath the sea floor.

5 For an overview see Gjerde, note 4 above, and UN Doc. A/61/154, of 14 July 2006, 'Impacts of fishing on vulnerable marine ecosystems: actions taken by States and regional fisheries management organizations and arrangements to give effect to paragraphs 66 to 69 of General Assembly Resolution $59 / 25$ on sustainable fisheries, regarding impacts of fishing on vulnerable marine ecosystems. Report of the Secretary-General', at pp. 8-9.

6 Cf. Gjerde, note 4 above, at pp. 6 and 22. 
land-based pollution. Also, the non-intentional impacts of marine capture fisheries are widely perceived as extremely wasteful and unnecessary.

The potential and actual rate of loss of marine biodiversity is a concern that is currently placed increasingly higher on the agendas of various intergovernmental fora at the global level. In the last few years they featured prominently in, inter alia, the Oceans and Fish Resolutions of the United Nations General Assembly (UNGA) and in the annual informal consultative process (ICP) on Oceans and the Law of the Sea, established by the UNGA. Biodiversity concerns were also addressed during the Review Conference of the Fish Stocks Agreement $^{7}$ (FSA Review Conference) ${ }^{8}$ held in May 2006, and were the primary focus of the first meeting of the Ad Hoc Open-ended Informal Working Group established by the UNGA to study issues relating to the conservation and sustainable use of marine biological diversity beyond areas of national jurisdiction, ${ }^{9}$ held in February 2006. In the context of the CBD, ${ }^{10}$ discussions took place on marine protected areas (MPAs) ${ }^{11}$ with a specific emphasis on MPAs in ABNJ, as well as on the conservation and sustainable use of deep seabed genetic resources in ABNJ. ${ }^{12}$ Finally, among the various relevant activities of the United Nations Food and Agriculture Organization (FAO) is the development of guidance on the use of MPAs as a fisheries management tool and on deep-sea fisheries. ${ }^{13}$ Various relevant activities have also taken place at intergovernmental fora at the regional level, such as the fora mentioned in Section 2.

The central purpose of this article is to identify the main shortcomings in the international legal framework relating to the conservation and sustainable

7 Agreement for the Implementation of the Provisions of the United Nations Convention on the Law of the Sea of 10 December 1982 relating to the Conservation and Management of Straddling Fish Stocks and Highly Migratory Fish Stocks, New York, 4 August 1995. In force 11 December 2001, 34 International Legal Materials 1542 (1995); <www.un.org/Depts/los>.

8 Report of the Review Conference on the Fish Stocks Agreement (UN Doc. A/CONF.210) 2006/15, of 5 July 2006).

9 The Report of this meeting is contained in UN Doc. A/61/65, of 20 March 2006.

10 See note 1 above.

11 For the purpose of this article, a MPA is regarded as a spatially defined area of the marine environment, in either two or three dimensions, where regulation for the purpose of conservation and sustainable use of marine biodiversity is more stringent than in the adjacent area. Reference should also be made to the definition of a MPA adopted by the General Assembly of the World Conservation Union (IUCN) in Resolution 17.38 (1988), reconfirmed in Resolution 19.46 (1994): "Any area of intertidal or subtidal terrain, together with its overlying water and associated flora, fauna, historical and cultural features, which has been reserved by law or other effective means to protect part or all of the enclosed environment."

12 See Doc. UNEP/CBD/WG-PA/1/6, of 20 June 2005, 'Report of the First Meeting of the Ad Hoc Open-ended Working Group on Protected Areas'; Conference of the Parties (CoP) Decision VIII/21 (2006) 'Marine and Coastal Biological Diversity: Conservation and Sustainable Use of Deep Seabed Genetic Resources Beyond the Limits of National Jurisdiction'; and CoP Decision VIII/24 (2006) 'Protected Areas', in particular paras. 35-47.

13 See the Report of the Twenty-Sixth Session of the Committee on Fisheries (COFI), Rome, 7-11 March 2005 (FAO Fisheries Reports No. R780), at paras. 83-95 and 100-103. An FAO expert consultation on MPAs for fisheries management took place in June 2006 and an FAO expert consultation on high seas deep-sea fisheries will be convened in November 2006. 
use of marine biodiversity in ABNJ and possible solutions for selected shortcomings. The article does not deal with the fair and equitable sharing of the benefits arising out of the utilization of genetic resources,${ }^{14}$ and, in relation to MPAs (in ABNJ), it only addresses the international institutional aspects. The focus is moreover limited to marine biodiversity in ABNJ, largely because, for various reasons, the focus of intergovernmental fora is directed at ABNJ. This, so it seems, makes reforms of the international legal framework relating to $\mathrm{ABNJ}$ the most likely as well. For the purpose of this article, ABNJ include the high seas and the Area as defined in the LOS Convention,,$^{15}$ as well as marine areas adjacent to territory situated south of $60^{\circ}$ South, even though the latter are also governed by the various instruments and bodies of the Antarctic Treaty System (ATS). The definition of ABNJ adopted in this article therefore includes areas of high seas that are above coastal States' (outer) continental shelves. ${ }^{16}$ As coastal States, in exercising their sovereign rights over their continental shelves, are entitled to regulate certain activities undertaken by third States, these areas of high seas are therefore not entirely 'beyond national jurisdiction'. Finally, for the purpose of this article, ABNJ also include the air space above them.

The next Section starts with a brief overview of the current international legal framework relating to the conservation and sustainable use of marine biodiversity in ABNJ. Section 3 then offers some preliminary considerations on the reform of this international legal framework. Subsequently, Section 4 elaborates on the need for reform in relation to some selected substantive issues, namely discrete high seas fish stocks, deep-sea species, integrated MPAs in ABNJ and, finally, on existing and new rights to conserve marine biodiversity. The article ends with some conclusions.

\section{Current International Legal Framework Relating to the Conservation and Sustainable Use of Marine Biodiversity in $A B N J$}

\section{General}

This Section's overview of the international legal framework relating to the conservation and sustainable use of marine biodiversity in $\mathrm{ABNJ}$ is limited to international instruments, intergovernmental organizations (IOs) and their acts that are directly relevant to the main human activities that may or do occur in ABNJ (as listed in Section 1). Obviously, it is not necessary for such instruments, IOs and acts to relate exclusively to ABNJ, as long as these areas are covered. Moreover, while only some of the instruments and acts mentioned

4 See Art. 1 of the CBD.

15 See note 2 above. Arts. 1(1)(1) and 86.

16 Both in cases where a coastal State has not established an exclusive economic zone (EEZ) or where its legal continental shelf extends beyond 200 nautical miles of the baseline in accordance with Art. 76 of the LOS Convention. 
in this Section specifically relate to sustainable use of marine biodiversity in ABNJ, all those referred to contribute to the conservation of marine biodiversity. The significance and directness of those contributions vary considerably and are usually closely related to the objective or mandate of an instrument or IO.

Of the main legally binding instruments adopted at the global level, the CBD and the LOS Convention-including the latter's two implementation agreements, namely the Part XI Implementation Agreement ${ }^{17}$ and the Fish Stocks Agreement - are the main framework treaties. Global treaties specifically related to particular species or groups of species are the CMS, ${ }^{18}$ CITES, ${ }^{19}$ the ICRW $^{20}$ and, in a sense, also the Compliance Agreement. ${ }^{21}$ In addition to the IOs that adopted these instruments (e.g., the FAO), as well as the international bodies operating under these instruments (e.g., the CoP under the CBD), special mention should be made of the following IOs that regulate particular human activities that may or do occur in ABNJ: the International Maritime Organization (IMO), the International Civil Aviation Organization (ICAO) and the International Seabed Authority (ISA). A variety of legally binding and nonlegally binding instruments and acts have been agreed upon in these IOs with, as mentioned above, varying contributions to marine biodiversity. Mention could be made here of MARPOL 73/7822 and the concept of particularly sensitive sea areas (PSSAs) ${ }^{23}$ adopted and developed in IMO, and the Regulations on Prospecting and Exploration of Polymetallic Nodules in the Area ${ }^{24}$ adopted in the ISA. Also worth mentioning is the London (Dumping) Convention, ${ }^{25}$ as amended by the 1996 Protocol. ${ }^{26}$

17 Agreement relating to the Implementation of Part XI of the United Nations Convention on the Law of the Sea of 10 December 1982, New York, 28 July 1994. In force 28 July 1996, 33 International Legal Materials 1309 (1994); <www.un.org/Depts/los>.

18 Convention on the Conservation of Migratory Species of Wild Animals, Bonn, 23 June 1979. In force 1 November 1983, 1651 United Nations Treaty Series 355; <www.cms.int>.

19 Convention on International Trade in Endangered Species of Wild Fauna and Flora, Washington, D.C., 3 March 1973. In force 1 July 1975, 993 United Nations Treaty Series 243; $<$ www.cites.org $>$.

20 International Convention for the Regulation of Whaling, Washington, D.C., 2 December 1946. In force 10 November 1948, 161 United Nations Treaty Series 72; <www.iwcoffice.org>.

21 Agreement to Promote Compliance with International Conservation and Management Measures by Fishing Vessels on the High Seas, Rome, 24 November 1993. In force 24 April 2003, 33 International Legal Materials 969 (1994); <www.fao.org/legal>.

22 International Convention for the Prevention of Pollution from Ships, London, 2 November 1973, as modified by the 1978 Protocol (London, 1 June 1978) and as regularly amended. Entry into force varies for each Annex. At the time of writing Annexes I-VI were all in force.

23 See IMO Assembly Resolution A.982(24), of 1 December 2005, 'Revised Guidelines for the Identification and Designation of Particularly Sensitive Sea Areas', which inter alia revokes Annex 2 of IMO Assembly Resolution A.927(22), of 29 November 2001 'Guidelines for the Designation of Special Areas under MARPOL 73/78 and Guidelines for the Identification and Designation of Particularly Sensitive Sea Areas'.

24 Doc. ISBA/6/A/18, of 4 October 2000. See Regs. 1(5), 3(4)(d)(i)(b), 21(4)(b) and 31-33.

25 Convention on the Prevention of Marine Pollution by Dumping of Wastes and Other Matter, London, Mexico City, Moscow, Washington, D.C., 29 December 1972. In force 30 August 1975, 11 International Legal Materials 1294 (1972); <www.londonconvention.org>.

261996 Protocol, London, 7 November 1996. In force 24 March 2006, <www.londonconvention.org>. 
With regard to marine scientific research and hydrographic research, reference can be made to the Intergovernmental Oceanographic Commission (IOC) of the United Nations Educational, Scientific and Cultural Organization (UNESCO) and the International Hydrographic Organization (IHO), respectively, even though these do not have regulatory roles. ${ }^{27}$

Finally, special reference should be made to the main relevant non-legally binding instruments, namely the FAO Code of Conduct, ${ }^{28}$ including the various international plans of action and technical guidelines adopted thereunder, and the JPOI, ${ }^{29}$ in particular its commitments on reducing loss of biodiversity and the establishment of MPAs. ${ }^{30}$

At the regional level, the main instruments and IOs relate to particular species and their habitats (agreements established under the $\mathrm{CMS}^{31}$ and the NAMMCO Agreement), ${ }^{32}$ to the management and conservation of fisheries resources (i.e., the constitutive instruments of regional fisheries management organizations (RFMOs) $)^{33}$ or more in general to marine environmental protection. Examples of the last category are the OSPAR Convention, ${ }^{34}$ the Helsinki Convention $^{35}$ and the agreements and action plans established under the United Nations Environment Programme (UNEP) Regional Seas Programme. ${ }^{36}$ However, the Helsinki Convention and several of the UNEP agreements and action plans do not also cover ABNJ and are therefore not relevant for the purpose of this Section's overview.

Both Polar Regions are governed by regulatory frameworks, but there are significant differences between them. The Arctic is covered by a variety of regimes with relevance to the marine environment. The most important are the Arctic Environmental Protection Strategy, the work of the Arctic Council, ${ }^{37}$ the ICES

27 Cf. Arts. 2 and 3 of the IOC Statutes (revised in November 1999; available at $<$ ioc.unesco.org $>$ ) and Art. 2 of the Convention on the International Hydrographic Organization (Monaco, 3 May 1967. In force 22 September 1970; <www.iho.shom.fr>).

28 Code of Conduct for Responsible Fisheries. Adopted by the Twenty-eighth Session of the FAO Conference, Rome, 31 October 1995, <www.fao.org/fi>.

29 Plan of Implementation of the World Summit on Sustainable Development, Johannesburg, 4 September 2002; <www.unep.org>.

30 Paras. 32 and 44.

31 See note 18 above. For an overview of these agreements see $<$ www.cms.int $>$.

32 Agreement on Cooperation in Research, Conservation and Management of Marine Mammals in the North Atlantic, Nuuk, 9 April 1992. In force 8 July 1992, Law of the Sea Bulletin No. 26, 66-68 (1994); <www.nammco.no>

33 For the purpose of this article, the acronym RFMO is meant to cover 'arrangements' in the sense of Art. 1(d) of the Fish Stocks Agreement.

34 Convention for the Protection of the Marine Environment of the North-East Atlantic, Paris, 22 September 1992. In force 25 March 1998, <www.ospar.org>. Note that Annex V to the OSPAR Convention is entitled "on the protection and conservation of the ecosystems and biological diversity of the maritime area."

35 Convention on the Protection of the Marine Environment of the Baltic Sea Area, Helsinki, 9 April 1992. In force 17 January 2000; <www.helcom.fi>.

36 For info see <www.unep.org/regionalseas $>$.

37 For info see $<w w w$.arctic-council.org $>$. 
Convention, ${ }^{38}$ the OSPAR Convention, the NAMMCO Agreement, the Treaty of Spitsbergen, ${ }^{39}$ the NEAFC Convention ${ }^{40}$ and the bilateral cooperation between Norway and the Russian Federation in the Barents Sea, including the 'Loophole'. However, the linkages between these regimes are often weak and large parts of the Arctic Ocean are not covered by various regimes..$^{41}$ By contrast, the Antarctic is governed by the ATS, which is an integrated framework, at least by intention. The ATS is built up around the Antarctic Treaty ${ }^{42}$ and is currently complemented by its Environmental Protocol, ${ }^{43}$ the CCAMLR Convention $^{44}$ and the CCAS. ${ }^{45}$ The relatively strong inter-institutional linkages in the ATS, the broad objectives of its instruments and the broad mandates of the IOs and bodies operating under them are particularly conducive to integrated (cross-sectoral) ecosystem management.

\section{Some Conclusions}

An obvious but still very pertinent conclusion of the short overview above is that the current international legal framework relating to the conservation and sustainable use of marine biodiversity in ABNJ is not laid down in a single treaty. Rather, it consists of a multitude of global, regional and bilateral legally binding and non-legally binding instruments and acts by IOs. As a whole, the framework is highly sectoralized and decentralized and suffers as a consequence not only from spatial and substantive gaps, but also from actual and potential overlaps. Apart from the Compliance Agreement, the ISA and the latter's acts, none of the identified global instruments and acts or mandates of global IOs relate exclusively to ABNJ. While the spatial mandates of some RFMOs are primarily aimed at $\mathrm{ABNJ},{ }^{46}$ most regional instruments and IOs also do not relate exclusively to ABNJ.

38 Convention for the International Council for the Exploration of the Sea, Copenhagen, 12 September 1964. In force 22 July 1968, 7 International Legal Materials 302 (1968); <www.ices.dk>.

39 Treaty on the Status of Spitsbergen, Paris, 9 February 1920. In force 14 August 1925; 2 League of Nations Treaty Series 8.

40 Convention on Future Multilateral Cooperation in the North-East Atlantic Fisheries, London, 18 November 1980. In force 17 March 1982, 1285 United Nations Treaty Series 129; $<$ www.neafc.org $>$.

41 In particular the NEAFC Convention, the ICES Convention, the OSPAR Convention and the NAMMCO Agreement.

42 The Antarctic Treaty, Washington, D.C., 1 December 1959. In force 23 June 1961, 402 United Nations Treaty Series $71 ;<$ www.ats.org.ar $>$.

43 Protocol on Environmental Protection to the Antarctic Treaty, Madrid, 4 October 1991 (Annexes I-IV). In force 14 January 1998; Annex V, Bonn, 17 October 1991 (adopted as Recommendation XVI-10). In force 24 May 2002; Annex VI, Stockholm, 14 June 2005 (adopted as Measure 1(2005)). Not in force. All texts available at <www.ats.org.ar $>$.

44 Convention on the Conservation of Antarctic Marine Living Resources, Canberra, 20 May 1980. In force 7 April 1982, 19 International Legal Materials 837 (1980); <www.ccamlr.org>.

45 Convention for the Conservation of Antarctic Seals, London, 1 June 1972. In force 11 March 1978, 1080 United Nations Treaty Series 176; <www.ats.org.ar>.

46 For instance, Arts. I and II of the NAFO Convention (Convention on Future Multilateral Cooperation in the Northwest Atlantic Fisheries, Ottawa, 24 October 1978. In force 
Spatial and substantive sectoral gaps exist, inter alia, in ABNJ that are not covered by RFMOs at all or only by RFMOs with a mandate that is limited to ensuring the conservation and sustainable use of certain target species. ${ }^{47}$ Similarly, there are large ABNJ that are not covered by regional marine environmental protection instruments. Moreover, the international legal framework relating to marine scientific research, bioprospecting, the laying of submarine cables and pipelines, and the construction of artificial islands in ABNJ-unless for the purpose of the exploration or exploitation of the resources of the Area-currently merely consists of general rights and obligations laid down in the LOS Convention and lacks a regulatory framework under which a global or regional IO has a regulatory mandate that includes (elements of) the conservation of marine biodiversity.

The current sectoral governance of the oceans is, inter alia, reflected in the parallel functioning of RFMOs and regional marine environmental protection instruments and bodies. Apart from the ATS, cooperation between them leaves much to be desired. A similar functional division is also pursued by the LOS Convention, which deals with the protection and preservation of the marine environment primarily in Part XII and with the conservation and utilization of marine living resources primarily in Part V and Section 2 of Part VII. However, the disadvantages of this traditional division of obligations under the LOS Convention are to some extent now addressed by the overarching obligations on the conservation and sustainable use of biodiversity under the CBD. ${ }^{48}$ These latter obligations are also applicable to ABNJ, even though they are only related to processes and activities. ${ }^{49}$

\section{Reform of the International Legal Framework: Preliminary Considerations}

\section{Introduction}

The logical point of departure in a discussion on the reform of the international legal framework relating to conservation and sustainable use of marine biodiversity in $\mathrm{ABNJ}$ is to assess the need for reforms in light of, inter alia, the threats to marine biodiversity in ABNJ. This is addressed in subsection 3.2. If the need for reform has indeed been ascertained, attention shifts to the form

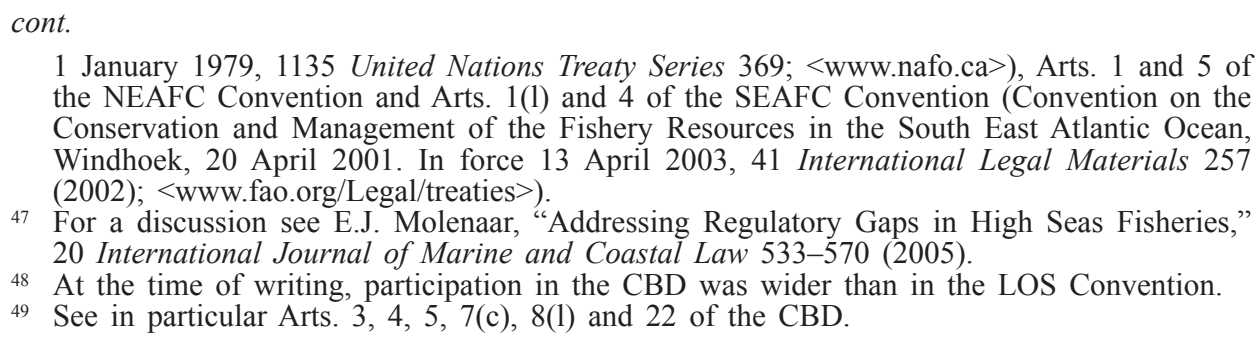

47 For a discussion see E.J. Molenaar, "Addressing Regulatory Gaps in High Seas Fisheries," 20 International Journal of Marine and Coastal Law 533-570 (2005).

48 At the time of writing, participation in the CBD was wider than in the LOS Convention.

49 See in particular Arts. 3, 4, 5, 7(c), 8(1) and 22 of the CBD. 
and level of reform, discussed in subsection 3.3. This phase includes, inter alia, a cost-benefit analysis of various options, partly in light of the severity of the threat to marine biodiversity and the urgency of reform. The outcome of this phase may well be that reform should not be undertaken. Section 4 examines the need for reform in relation to some selected substantive issues.

\section{The Need for Reforms}

In addition to the selected substantive issues examined in more detail in Section 4, two obvious shortcomings of the international legal framework identified in subsection 2.2 are spatial and substantive gaps in terms of marine capture fisheries. The need to establish new RFMOs or arrangements and to broaden the mandate and enhance the performance of existing RFMOs is widely recognized. ${ }^{50}$ Recent initiatives to address these shortcomings include the commencement of a negotiation process for the establishment of RFMOs in the Southern Pacific ${ }^{51}$ and in the North-West Pacific, ${ }^{52}$ initiatives to reform the NAFO Convention ${ }^{53}$ and the NEAFC Convention, ${ }^{54}$ and self-assessments of performance. ${ }^{55}$ These latter initiatives are a direct response to the present troublesome state of marine capture fisheries worldwide and acknowledge the substandard performance of these (and other) RFMOs, notwithstanding the many other causes for the current state of marine capture fisheries, such as illegal, unreported and unregulated (IUU) fishing.

Subsection 2.2 also ascertained that many ABNJ are not covered by regional marine environmental protection instruments and bodies. Possibly, the mandate and performance of those that do cover ABNJ are in need of improvement as well. ${ }^{56}$ Also lacking are regulatory frameworks with competent IOs for certain human activities - such as marine scientific research - that are carried out in $\mathrm{ABNJ}$, if they are unrelated to the exploration or exploitation of the resources of the Area. There may well be a need for reform of the international legal framework on these aspects. ${ }^{57}$ The form and level of such reforms may then

50 For some info see Molenaar, note 47 above, at pp. 540-545 and 548-551.

51 For some info see Molenaar, note 47 above, at pp. 542-544 and <www.southpacificrfmo.org>.

52 An informal meeting attended by delegations from Japan, the Russian Federation and South Korea was held 11-13 April 2006 in Tokyo, Japan. The First Intergovernmental Meeting on Establishment of [a] New Mechanism for Management of High Seas Bottom Trawling in the North Western Pacific Ocean was held 22-24 August 2006, also in Tokyo. In addition to the three States mentioned earlier, the United States (as a coastal State) also attended (Doc. NWPBT/01/Rec rev2 (on file with author) and information provided by C. Ahn, Ministry of Maritime Affairs and Fisheries of South Korea, August 2006; see also Doc. A/CONF.210/2006/15, note 8 above, at p. 13, para. 61).

53 See note 46 above.

54 See note 40 above. Cf. Doc. A/CONF.210/2006/15, note 8 above, at p. 32, para. 9.

55 Both the International Commission for the Conservation of Atlantic Tunas (ICCAT) and NEAFC have already started such assessments (cf. Doc. A/CONF.210/2006/15, note 8 above, at p. 19, para. 88).

56 See also Gjerde, note 4 above, at pp. $45-46$.

57 See UN Doc. A/61/65, note 9 above, at p. 8, para. 27 and p. 17, paras. 65-66 and Gjerde, note 4 above, at p. 45. 
be guided by the identified need to move from sectoral governance towards integrated ecosystem-based oceans management. A true merger of RFMOs and regional marine environmental protection bodies seems to be an idea of the distant future, however.

\section{The Form and Level of Reforms}

In view of the decentralized nature of international law and the absence of hierarchy among its forms/manifestations as well as its law-making processes, particular care should be taken to ensure that the proposed reform minimizes competition or overlap with existing legal regimes. This is especially pertinent with regard to the European Union's (EU) proposal to commence negotiations on an Implementation Agreement to the LOS Convention, whose main objective would be:

"conservation and management of marine biological diversity, including the establishment, on an integrated, scientific and precautionary basis, of marine protected areas in areas beyond national jurisdiction." ${ }^{58}$

Many States are not convinced of the need for such an Implementation Agreement at all and feel that negotiations will consume much time, money and effort that could be better used, especially at the regional level. ${ }^{59}$ Some may even argue that the proposal for, and the negotiation of, an Implementation Agreement is a deliberate ploy to avert reforms from where they are needed most: at the regional level. Much of this criticism is motivated by strongly held opinions on the various mandates of relevant international organizations and their primacy vis-à-vis each other. Some States with significant fisheries interests strongly guard the influence-including in decision-making processes - they currently have at the regional level. They fear that their less significant influence - including in decision-making processes - at the global level will ultimately lead to a repetition of the history of the IWC. Although the IWC was intended to be a science-based governance body, it has become a conservation body where the decision-making procedure allows States without any intention to engage in exploitation to base decisions primarily on political, cultural or ethical considerations. These States therefore see the aforementioned proposed reform at the global level as an attempt to ensure that the interests of conservation of marine biodiversity or non-utilization of marine living resources become superior to the socio-economic interests of utilization, as well as a threat to science-based fisheries management.

\footnotetext{
58 See the Annex to the Statement by Austria, on behalf of the EU, at the 7th Meeting of the ICP (2006). See also UN Doc. A/61/65, note 9 above, at p. 8, para. 25.

59 See UN Doc. A/61/65, note 9 above, at p. 15 , para. 55 .
} 


\section{Reform of the International Legal Framework: Selected Substantive Issues}

\section{Discrete High Seas Fish Stocks}

The term 'discrete high seas fish stocks' ${ }^{\prime 0}$ has in recent years been used to denote fish stocks that occur ${ }^{61}$ exclusively on the high seas and not within adjacent maritime zones of coastal States. While discrete high seas fish stocks are currently covered by Section 2 of Part VII of the LOS Convention and other global legally binding and non-legally binding international instruments, ${ }^{62}$ they are not covered by the Fish Stocks Agreement. ${ }^{63}$ This gap in the global legal framework has attracted significant attention as a consequence of bottom trawling for deep-sea species, which also target discrete high seas fish stocks.

The term 'discrete high seas fish stocks' does not seem to have been defined in an international instrument. The description above implicitly uses the definition of 'fish' in Article 1(1)(c) of the Fish Stocks Agreement, by which fish "includes molluses and crustaceans except those belonging to sedentary species as defined in article 77 of the [LOS] Convention." However, the use of this definition of fish for the purpose of discrete high seas fish stocks needs to be carefully considered in light of the fact that the target species covered by the constitutive instruments of all present non-tuna RFMOs and Arrangements, except for the current text of the NEAFC Convention, explicitly or potentially includes all marine living resources, or explicitly includes sedentary species as defined in Article 77(4) of the LOS Convention. ${ }^{64}$ As reform should avoid legal gaps in the global legal framework and should also aim for consistency with the regional legal framework, it would be preferable

60 For an overview of discrete high seas fish stocks see UN Doc. A/CONF.210/2006/1, of 4 January 2006, 'Report submitted in accordance with paragraph 17 of General Assembly Resolution 59/25 of 17 November 2004, to assist the Review Conference to implement its mandate under paragraph 2, Article 36 of the United Nations Fish Stocks AgreementReport of the Secretary-General', at pp. 23-26, paras. 104-114.

61 The verb 'occur' is chosen to maintain consistency with the wording of Art. 63 of the LOS Convention, even though it may not always offer fisheries management authorities and others sufficient guidance for the classification of stocks. It is submitted that the discreteness or not of a stock depends first of all on the significance of transboundary effects of exploitation (for a discussion see E.J. Molenaar, "The South Tasman Rise Arrangement of 2000 and other Initiatives on Management and Conservation of Orange Roughy", 16 International Journal of Marine and Coastal Law 77-118 (2001), at pp. 85-89).

62 E.g., the Compliance Agreement, the Code of Conduct and its international plans of action.

${ }^{63}$ For an alternative view see M.W. Lodge and S.N. Nandan, "Some Suggestions Towards Better Implementation of the United Nations Agreement on Straddling Fish Stocks and Highly Migratory Fish Stocks of 1995," 20 International Journal of Marine and Coastal Law 345-379 (2005), at p. 371.

${ }^{64}$ Cf. E.J. Molenaar, "Current Legal and Institutional Issues Relating to the Conservation and Management of High Seas Deep Sea Fisheries," background paper prepared for the FAO Expert Consultation on Deep Sea Fisheries on the High Seas, Bangkok, 21-23 November 2006, at subsections 3.2 and 4.2.1. 
to also include sedentary species in a definition of fish used in a definition of discrete high seas fish stocks. ${ }^{65}$ But this would not only broaden the species coverage but also the spatial coverage. While outer continental shelves were already excluded due to the sovereign rights of coastal States over sedentary species, the spatial scope would be broadened by the inclusion of sedentary species ocurring in the Area. Instead of applying to discrete high seas fish stocks, it would apply to fish stocks discrete to ABNJ.

The need to address the gap in coverage of discrete high seas fish stocks in the global legal framework has been recognized repeatedly during the last few years, for instance at the St. John's Conference in May 2005. ${ }^{66}$ Subsequently, in its 2005 Fish Resolution, the UNGA encouraged "States, as appropriate, to recognize that the general principles of the [Fish Stocks Agreement] should also apply to discrete fish stocks in the high seas". The exact same wording was chosen by the FSA Review Conference in May 2006. ${ }^{67}$ Little or no support existed for a call to ensure that the provisions of the Fish Stocks Agreement apply to all stocks. ${ }^{68}$ The lack of support for advocating such an approach can be explained by the special character of the FSA Review Conference, as well as the understandable priority given to preserving the package deal of the Fish Stocks Agreement and consolidating universal participation in it. ${ }^{69}$ Moreover, there was sufficient support for the view that:

"[RFMOs] with competence to regulate straddling fish stocks have the necessary competence to conserve and manage high-seas discrete stocks. There is no obstacle for such [RFMOs] to adopt management measures in respect of such stocks in accordance with the general principles set forth in the [Fish Stocks Agreement]. ${ }^{.70}$

In fact, the objectives of the RFMOs and Arrangements that currently regulate straddling fish stocks within the meaning of Article 63(2) of the LOS Convention do not contain wording related to the classification of stocks. This is so for the CBS Convention, ${ }^{71}$ the CCAMLR Convention, ${ }^{72}$ the GFCM

65 If that option is pursued, however, it also seems necessary to incorporate a definition of 'fishing activities' that ensures that marine genetic resources and bioprospecting are excluded from the scope of the instrument. Such definitions can be found in many of the constitutive instruments of the newer RFMOs.

66 See para. 13(A) of the Ministerial Declaration adopted at the 'Conference on the Governance of High Seas Fisheries and the UN Fish Agreement: Moving from Words to Action', available at <www.dfo-mpo.gc.ca/fgc-cgp $>$.

67 Cf. Doc. A/CONF.210/2006/15, note 8 above, at p. 31, para. 2.

68 See also Lodge and Nandan, note 63 above, at pp. 369-373.

69 Japan's ratification of the Fish Stocks Agreement on 7 August 2006 is an important step towards more universal participation.

70 Doc. A/CONF.210/2006/15, note 8 above, at p. 33, para. 16. Cf. also Lodge, note 3 above, at p. 307. For a different view see M. Hayashi, "Global Governance of Deep-Sea Fisheries," 19 International Journal of Marine and Coastal Law 289-316 (2004), at pp. 295-297.

71 Convention on the Conservation and Management of Pollock Resources in the Central Bering Sea, Washington, 16 June 1994. In force 8 December 1995, 34 International Legal Materials 67 (1995); <www.afsc.noaa.gov/refm/cbs>.

72 See in particular Art. I(1). 
Agreement, ${ }^{73}$ the NAFO Convention, ${ }^{74}$ the NEAFC Convention ${ }^{75}$ and the SEAFC Convention. ${ }^{76}$

The STR Arrangement ${ }^{77}$ is a special case because Australia and New Zealand were unable to agree on whether orange roughy in the regulatory area was a discrete high seas fish stock or not. ${ }^{78}$ It is also noteworthy that the objective of the SIOF Agreement ${ }^{79}$ is similar to those of the other RFMOs and Arrangements, even though its negotiation process was primarily aimed at establishing a regulatory framework for discrete high seas fish stocks. ${ }^{80}$ This similarity also exists with respect to the objectives of the SEAFC Convention and the Draft SPOF Agreement, ${ }^{81}$ even though both were/are negotiated in full awareness of the presence of discrete high seas fish stocks in the (envisaged) regulatory area. ${ }^{82}$ It is of course too early to say anything about the objective of a possible NWPOF Agreement. ${ }^{83}$ But it is worth noting that in the envisaged regulatory area there may well be discrete high seas fish stocks of pelagic armourhead (Pseudopentaceros wheeleri and P. richardsoni), alfonsino (Beryx splendens) and oreo dories (Allocyttus spp., Neocyttus spp. and Pseudocyttus spp.). ${ }^{84}$

73 Agreement for the establishment of a General Fisheries Council for the Mediterranean (Rome, 24 September 1949. In force 20 February 1952, 126 United Nations Treaty Series 239). Amendments adopted by the FAO Council at its 113th Session in November 1997 entered into force on 29 April 2004; amended version available at <www.fao.org/Legal/>. See the Preamble.

74 See Art. I(4)

75 See Art. 1(2).

6 See note 46 above. See Art. 1(1) and (n).

77 Arrangement between the Government of Australia and the Government of New Zealand for the Conservation and Management of Orange Roughy on the South Tasman Rise. Signed for New Zealand on 17 February 2000 and for Australia on 25 February 2000. In effect on 1 March 2000; text at 16 International Journal of Marine and Coastal Law 119-124 (2001).

78 See the Preamble.

79 Southern Oceans Fisheries Agreement, Rome, 7 July 2006. Not in force, text on file with author. See Arts. 1(c) and (f) and 3 .

80 For some information about the complex negotiation process of the SIOF Agreement see Molenaar, note 61 above, at pp. 109-115, as well as Molenaar, note 47 above, at pp. 541-542. A formal account of the negotiation process is incorporated in the 'Final Act of the Conference on the Southern Indian Ocean Fisheries Agreement', which was adopted on 7 July 2006.

81 Chair's Draft Pacific Ocean Regional Fisheries Management Agreement of 8 September 2006, text at <www.southpacificrfmo.org $>$. See Art. 2

82 As regards the SEAFC Convention, see A. Jackson, "The Convention on the Conservation and Management of Fishery Resources in the South East Atlantic Ocean 2001: An Introduction," 17 International Journal of Marine and Coastal Law 33-77 (2002), at pp. 38 and 47. As regards the Draft SPOF Agreement, see Doc. SP/01/WP1 (February 2006), at pp. 1-2. Note also that Art. 26(2) of the Draft SPOF Agreement refers explicitly to Arts. 116-119 of the LOS Convention. This could be primarily related to the issue of non-parties to the Fish Stocks Agreement, to the issue of high seas discrete fish stocks, or to both.

83 North West Pacific Ocean Fisheries Agreement.

84 Information provided by C. Ahn, Ministry of Maritime Affairs and Fisheries of South Korea, August 2006. See also UN Doc. A/CONF.210/2006/1, supra note 60, at pp. 25-26, para. 113. Agreement-Report of the Secretary-General' (UN Doc. A/CONF.210/2006/1, of 4 January 2006), at pp. 25-26, para. 113. 
The fact that the SEAFC Convention, the SIOF Agreement and the Draft SPOF Agreement ${ }^{85}$ were (are) negotiated in full awareness of the presence of discrete high seas fish stocks in the (envisaged) regulatory area is also important because (a) they were (are) negotiated after the adoption of the Fish Stocks Agreement and (b) their texts draw heavily on the Fish Stocks Agreement. The GFCM Agreement cannot be grouped together with these. ${ }^{86}$ The STR Arrangement is once again a special case because it is non-legally binding and only Australia was a party to the Fish Stocks Agreement at the time when it signed the Arrangement. It nevertheless draws on the Fish Stocks Agreement in spite of the disagreement on stock classification. At the time of writing, all the participants in the NWPOF Agreement initiative, except South Korea, were party to the Fish Stocks Agreement. The likelihood that the Fish Stocks Agreement will be extensively drawn on would therefore seem considerable.

The constitutive instruments of various RFMOs and Arrangements seem to indicate that parts of the Fish Stocks Agreement are, in various ways, potentially already being applied to discrete high seas fish stocks. The objectives of relevant RFMOs and Arrangements are formulated in a general way, without classifying stocks or species as straddling or discrete high seas fish stocks. It seems, therefore, that the competence of all these RFMOs and Arrangements thereby covers discrete high seas fish stocks as well. There are no indications that these RFMOs and Arrangements, in performing their functions, explicitly or implicitly distinguish between straddling and discrete high seas fish stocks. Perhaps apart from the issue of the allocation of fishing opportunities, such a distinction would also not be warranted by scientific, pragmatic or other factors. However, this state practice 'merely' consists of the texts of constitutive instruments. Arguably, state practice has more weight if it consists of actual conservation and management measures that apply explicitly or implicitly to discrete high seas fish stocks and which are adopted and applied in accordance with the Fish Stocks Agreement.

The cited view expressed at the FSA Review Conference suggests that the international community currently has a preference for a regional solution for the identified gap in the global international legal framework. State practice through RFMOs and Arrangements would ensure that all members and participants are under a legal obligation to apply the Fish Stocks Agreement mutatis

85 The Draft SPOF Agreement refers explicitly to the LOS Convention and the Fish Stocks Agreement in its Preamble. By contrast, the Report of the 'First International Meeting on the Establishment of the proposed South Pacific Regional Fisheries Management Organisation' (February 2006) merely contains a footnote with the following text: "Participants understood that the new instrument should, as far as possible, avoid duplication and overlap with existing international instruments and should be consistent with [the] international law relating to law of the sea" (at para. 6(i)).

86 Although the 1997 amendments to the GFCM Agreement were also approved after the adoption of the Fish Stocks Agreement, the current text of the GFCM Agreement does not draw on the Fish Stocks Agreement and the 1997 amendments were also not adopted in the face of full awareness of the presence of discrete high seas fish stocks in the regulatory area. 
mutandis equally to discrete high seas fish stocks. However, as such a regional approach has various shortcomings, the international community may still decide on developing a legally binding international instrument in parallel in a less sensitive setting than the FSA Review Conference. ${ }^{87}$

It should finally be mentioned that the proposal put forward at the FSA Review Conference for FAO to develop technical guidelines on the conservation and management of discrete high seas fish stocks found insufficient support. One observer openly wondered what the benefit of such guidelines would be. ${ }^{88}$ Provided that the FAO revises its global fisheries statistics database to facilitate the identification of potential discrete high seas fish stocks, ${ }^{89}$ this is an understandable concern. As most discrete high seas fish stocks are in fact deep-sea species, ${ }^{90}$ it would be better for the FAO to focus on deep-sea species and fisheries. This is examined in more detail in subsection 4.2.

\section{Deep-Sea Species and Fisheries}

The current debate on bottom trawling for deep-sea species has arisen out of three different main concerns. First, in certain circumstances, bottom trawling can be destructive due to high by-catch and serious impacts on the benthos. Second, many deep-sea species are long-lived and slow-growing species with late maturity and low fecundity and some species or populations have small ranges of distribution or aggregate periodically, for instance around seamounts. The consequential high risk of over-exploitation and collapse of stocks is further increased due to the fact that scientific understanding of the biological characteristics of many deep-sea species is generally very limited. Third, some of the deep-sea fisheries on the high seas - whether targeting straddling or discrete high seas fish stocks - have occurred and are still occurring, despite the absence of adequate international regulation. The fishery for orange roughy in the South-West Indian Ocean, which probably had its peak in 2000 or 2001, is a notorious example of a deep-sea fishery for a discrete high seas fish stock that completed the 'boom-and-bust' cycle well before a regional fisheries management mechanism was in place. In fact, it was still not in place when this article was written..$^{91}$

The push for an UNGA moratorium on high seas bottom trawling ${ }^{92}$ attempts to address all three of these concerns, even though the side-effects of this fishing practice are prima facie the primary focus. Whether or not some form of an UNGA moratorium on high seas bottom trawling will be adopted, there

\footnotetext{
For some of the pros and cons see the analysis by Molenaar, note 64 above, at subsection 4.2.1.

Cf. Doc. A/CONF.210/2006/15, note 8 above, at p. 14, paras. 64-65.

89 As recommended by the Conference at p. 35, para. 19 of Doc. A/CONF.210/2006/15, note 8 above.

90 Cf. UN Doc. A/CONF.210/2006/1, note 60 above, at p. 23, para. 104.

91 See note 80 above.

92 See, inter alia, Recommendation 3.099 adopted by the IUCN World Conservation Congress in 2004 (available at <www.iucn.org/congress $>$ ).
} 
still remains a need to address the high risk of over-exploitation of deep-sea species. In view of FAO's technical and scientific expertise in the sphere of marine capture fisheries, it seems only logical that the FAO undertake this task. One option, which is already under way, ${ }^{93}$ is to develop guidance on deep-sea species and (new and exploratory) deep-sea fisheries, possibly in the form of Technical Guidelines in the framework of the Code of Conduct. It would seem to be especially pertinent for these Guidelines to determine whether Annexes I and II to the Fish Stocks Agreement need adjustment in view of the characteristics of deep-sea species and (new and exploratory) deep-sea fisheries. ${ }^{94}$

The international community may of course feel that the risk of loss of marine biodiversity posed by deep-sea fisheries is so high that reliance on voluntary implementation of non-legally binding FAO instruments by coastal States, flag States, RFMOs and other actors is not regarded as sufficient. Some States already felt that way during COFI's 26th Session in 2005..$^{95}$

As regards the substance, the instrument may as a minimum contain the suggestions made above in relation to the collection and sharing of data and the precautionary approach. More in general, in view of the decentralized nature of international law and the absence of hierarchy among its forms/manifestations as well as its law-making processes, particular care should be taken to ensure that the proposed reform minimizes competition or overlap with existing legal regimes. The most directly relevant legal regimes are of course existing RFMOs and Arrangements. On the other hand, it may also be argued that the conservation and management of deep sea fisheries and species would benefit from global regulation as well. This could take various forms. One form would be for the instrument to mandate a new or existing global body to assess the risk of fishing for certain deep-sea species or the risk of using certain fishing practices. Of the existing global bodies, possible candidates would be COFI, the UNGA or the UN Trusteeship Council. ${ }^{96}$

93 See note 13 above.

94 Account may also be taken here of the work in the International Council for the Exploration of the Sea (ICES; as advocated in UN Doc. A/CONF.210/2006/1, note 60 above, at p. 24, para. 108) and the work of the FAO Ad Hoc Expert Advisory Panel for Assessment of Listing Proposals for Commercially Exploited Aquatic Species (see FAO Fisheries Reports No. R780, note 13 above, at p. 9, para. 54).

95 FAO Fisheries Reports No. R780, note 13 above, at p. 14, para. 86.

96 P. Sands, Principles of International Environmental Law (Cambridge, Cambridge University Press, 2nd edition, 2003), p. 94, reports that President Gorbachev of the Soviet Union proposed in 1990 to expand the function of the Council "to include responsibility for environmental protection in areas beyond national jurisdiction, the global commons." Also noteworthy is Malta's proposal to change the role of the Council into a guardian and trustee of the resources of the global commons (as reported by S. Busuttil and K. Yazaki, "Preface" in A. Agius and S. Busuttil with T. Kim and K. Yazaki (eds) Future Generations and International Law (London, Earthscan Publication: 1998), at p. xi). Note also that para. 178 of UNGA Resolution 60/1, of 16 September 2005, reads: "Considering that the Trusteeship Council no 
One step further would be to give that new or existing body or oceans trust the competence to regulate deep-sea fisheries globally. ${ }^{97}$ However, in view of the fierce opposition by some States to blanket moratoria and a species-byspecies (instead of a stock-by-stock) approach-inspired by the moratorium on commercial whaling, the listing of certain whale species on the Annexes of CITES and the suitability of the CITES listing criteria to commercially exploited aquatic species - this alternative is not likely to find sufficient support. Possibly, however, support would be broader if the global body is only given a mandate by default, namely in the absence of an RFMO or Arrangement with spatial and substantive competence. ${ }^{98}$ It is worth noting that a mandate-by-default rationale is also a crucial element in current proposals by various States for a recommendation by the UNGA on high seas bottom trawling.

\section{Integrated Marine Protected Areas in ABNJ}

The current interest in MPAs in ABNJ in various global fora is to a large extent linked to bottom trawling for deep-sea species. As bottom trawling can have significant impacts on the benthos - for instance cold-water coral reefsspatial regulation is a logical remedy. Concern has also been expressed about the impacts of marine scientific research and bioprospecting on hydrothermal vents. Apart from the special case of the Mediterranean, where many States have not established EEZs or exclusive fishery zones, interest in MPAs in ABNJ was only marginal a few years ago.

It should be recognized that, in view of the definition of MPAs used in this article, ${ }^{99}$ several international instruments already provide for the designation of MPAs with more stringent regulation therein, albeit only sectorally. For example, special areas under MARPOL 73/78, PSSAs, and spatial conservation and management measures (e.g., closed areas) adopted by RFMOs can include ABNJ. It should also be noted that the Commission for the Conservation of Antarctic Marine Living Resources (CCAMLR) is currently developing

\section{cont.}

longer meets and has no remaining functions, we should delete Chapter XIII of the Charter and references to the Council in Chapter XII."

97 See M.W. Lodge, "Improving International Governance in the Deep Sea," 19 International Journal of Marine and Coastal Law 299-316 (2004), at p. 307, R. Shotton and M. Haward, "Requirements for Managing Deep-Sea Fisheries," in R. Shotton (ed.) Deep Sea 2003: Conference on the Governance and Management of Deep-sea Fisheries (FAO Fisheries Proceedings, FAO: 2005), Part 1: Conference reports, at pp. 704-709, G. Osherenko, "New Discourses on Ocean Rights: Understanding Property Rights, the Public Trust, and Ocean Governance," ExpressO Preprint Series, paper 1537 (2006), at p. 67 and P.H. Sand, "Public Trusteeship for the Oceans" in Liber Amicorum for Thomas A. Mensah (forthcoming in 2006; draft of 12 September 2006).

98 See also note 118 below and accompanying text.

99 See note 11 above. 
a system of marine protected areas ${ }^{100}$ and that the establishment of criteria and procedures for closing areas to fisheries is underway in the North-East Atlantic Fisheries Commission (NEAFC). ${ }^{101}$

It is submitted that the mandate and legitimacy of the IMO and RFMOs are in principle beyond doubt and that their spatial measures are therefore capable - at least potentially - of affecting the rights and freedoms of third States, even if not through non-flag enforcement on the high seas. By contrast, the current international legal framework relating to ABNJ lacks both a mandate and a process for the designation of integrated MPAs in ABNJ as well as for the regulation of all human activities therein, for the purpose of the conservation and sustainable use of marine biodiversity. ${ }^{102}$ In the absence of these, designation of MPAs in ABNJ and regulation of activities therein lack legitimacy and make interference with the freedoms of the high seas by third States unjustifiable, except if such interference is based on rights under customary international law. ${ }^{103}$ A good example, even though highly commendable, is the recent implicit designation by four fishing companies cooperating within the Southern Indian Ocean Deepwater Fishers' Association (SIODFA) of eleven MPAs in ABNJ of the southern Indian Ocean where bottom trawling is halted. 104

While support for the need for integrated MPAs in ABNJ seems to be growing, there is still no certainty as to where the criteria for the designation of MPAs and representative networks of MPAs, or the process for their designation, should be developed. States that support the EU's proposal for an Implementation Agreement to the LOS Convention probably see integrated MPAs in ABNJ as one of its main elements. ${ }^{105}$ The already mentioned need to minimize competition or overlap with existing legal regimes, in particular RFMOs, is especially pertinent for integrated MPAs in ABNJ. A source of inspiration and guidance could be the way in which the identification and designation of PSSAs are distinguished from the adoption of associated protective measures therein, as well as the respective roles of the Committee on Environmental Protection (CEP) and CCAMLR in relation to the designation of Antarctic Specially Protected Areas and Antarctic Specially Managed Areas containing marine areas under Annex V to the Protocol on Environmental Protection to the Antarctic Treaty. ${ }^{106}$

100 See the Report of the 24th Annual CCAMLR Meeting (2005) (Doc. CCAMLR-XXIV), at paras. 4.12-4.18.

101 See the Final Report of the Working Group on the Future of NEAFC (7-9 February 2006), at pp. 4-6.

102 See also T. Scovazzi, "Marine Protected Areas on the High Seas: Some Legal and Policy Considerations," 19 International Journal of Marine and Coastal Law 1-19 (2004).

103 For an example see note 161 below and accompanying text.

104 See the news release of 6 July 2006 at <www.iucn.org>.

${ }_{105}$ See UN Doc. A/61/65, note 9 above, at pp. 16-17, paras. 59-62 and Doc. A/CONF.210/ $2006 / 15$, note 8 above, at pp. 33-34, paras. 15 and $18(\mathrm{e})$.

106 See Art. 6(2) of Annex V, the procedure laid down in ATCM (Antarctic Treaty Consultative 


\section{Existing and New Rights to Conserve Marine Biodiversity}

\section{Introduction}

Reforms of international law are above all a matter of striking an acceptable balance between opposing needs and interests that exist at a given time in the international community. A number of acceptable balances must be struck to successfully reform the international legal framework relating to the conservation and sustainable use of marine biodiversity in ABNJ. At a high level, reform is guided by the universal but flexible goal of sustainable development and thereby pursues an equitable balance between socio-economic interests and the interests in marine biodiversity by present and future generations. As reform should minimize competition or overlap with existing legal regimes, this balance includes an equitable balance between new and existing legal regimes at the global and regional level.

It is submitted that another necessary balance that such reform should strike is that between rights and obligations of States to conserve marine biodiversity. In view of the current rate of loss of marine biodiversity, reform should not just be limited to the traditional approach of strengthening, deepening and broadening obligations, but should be balanced with optimizing the use of existing rights and/or granting new rights to ensure that the overarching balance is achieved.

It is nevertheless acknowledged that many States regard the granting of new rights - to other States, as it were - as more far-reaching restrictions on their sovereignty, sovereign rights or jurisdiction than the obligations that they have imposed on themselves, as it were. The inclusion of the non-flag State enforcement rights pursuant to Articles 21 and 22 of the Fish Stocks Agreement, even though quite limited and carefully circumscribed, and of similar rights in the constitutive instruments of several RFMOs, ${ }^{107}$ was very controversial and contributed considerably to not only delaying the negotiation processes but also to the present limited participation in the treaties. Moreover, at the time of writing, no State seems to have used these rights and no RFMO has yet adopted procedures that would allow high seas enforcement against ships of non-members to which the captain or the flag State has not given their consent. ${ }^{108}$ Likewise, few States seem to have adopted legislation enabling them to exercise the right granted to port States pursuant to Article 218 of the LOS

cont.

Meeting) Decision 9 (2005) 'Marine Protected Areas' and ATCM Doc. XXIX/WP.4 (2006)

'Marine Protected Areas (MPAs) - Tools for Protection and Management'.

107 See Art. 16 of the SEAFC Convention, note 46 above, and Art. 26 of the WCPFC Convention (Convention on the Conservation and Management of Highly Migratory Fish Stocks in the Western and Central Pacific Ocean, Honolulu, 5 September 2000. In force 19 June 2004, 40 International Legal Materials 277 (2001); <www.wcpfc.org>).

108 For a discussion see R.G. Rayfuse, Non-Flag State Enforcement in High Seas Fisheries (Leiden/Boston, Martinus Nijhoff Publishers: 2004). 
Convention, namely to institute proceedings with regard to illegal discharges occurring beyond their own maritime zones. This right does not seem to have actually been ever used either. ${ }^{109}$ However, the mere existence of these rights and their potential use may still have a positive impact on compliance. ${ }^{110}$ Moreover, the fact that these rights have not or hardly been used cannot serve as an argument against the incorporation of rights per se. Their limited use may just as well be due to the constraints to which the right is subject.

The subsections below examine the need for optimizing the use of existing rights and/or granting new rights through a general but explicit right of States to marine biodiversity, rights of non-user States in RFMOs, the right to underutilize allocations of fishing opportunities, coastal State jurisdiction over the (outer) continental shelf, port State jurisdiction and non-flag States and the genuine link.

\section{A General but Explicit Right of States to Marine Biodiversity}

The current international legal framework relating to the conservation and sustainable use of marine biodiversity (in ABNJ) does not contain a general but explicit right of States to marine biodiversity. What is meant is a right that explicitly acknowledges the various values associated with (marine) biodiversity, ${ }^{111}$ including conservation for the purpose of long-term sustainable use, as well as non-use for an indefinite period for other reasons. Moreover, such a right would be granted to States, instead of to individuals or future generations, with the States acting either on behalf of their present generations or as guardians or custodians on behalf of their future generations.

Even though such a general but explicit right is lacking, the current international legal framework contains many implicit acknowledgments of such a right. This is implied, for instance, in the general and specific obligations for the protection and preservation of the marine environment and for the conservation and sustainable utilization of marine living resources laid down in the LOS Convention. These obligations are accompanied by rights for the same purposes, which are implied in these obligations or in the recognition of sovereignty, sovereign rights, jurisdiction or freedoms of States. Moreover, as regards marine mammals, Article 65 explicitly recognizes the right of coastal States and the appropriate international organization to regulate the exploitation of marine mammals more strictly than provided by Part V of the LOS Convention. ${ }^{112}$ A right to marine biodiversity is similarly implied in one of the objectives of the CBD, namely the conservation of biodiversity. While the CBD lacks a general obligation to conserve biodiversity, it contains a large

109 For a discussion see E.J. Molenaar, "Port State Jurisdiction: Towards Comprehensive, Mandatory and Global Coverage," Ocean Development \& International Law (2007; forthcoming).

110 See also note 117 and accompanying text.

111 See note 1 above and accompanying text.

112 This should be read as a reference to the objective of optimum utilization as laid down in Art. 62(1) 
number of specific obligations to conserve components of biodiversity and its Preamble affirms that the conservation of biodiversity is the "common concern of humankind."

Mention should also be made of relevant human rights or entitlements, as laid down in national legislation or international instruments. ${ }^{113}$ Also, while the responsibility of the international community and arguably also of individual States to take account of the interests of future generations is not beyond challenge, ${ }^{114}$ no legally binding global instrument today contains an explicit right for future generations. Some nevertheless advocate the view that intergenerational rights and equity are already rooted in international law. ${ }^{115}$

For some, the incorporation of a general right of States to marine biodiversity in the international legal framework-for instance in the body of, or Preamble to, the proposed Implementation Agreement to the LOS Conventionis merely a matter of semantics that changes nothing in the substance of the existing international legal framework. However, in view of the objective of striking an equitable balance between socio-economic interests and the interests in marine biodiversity by present and future generations, those interests should, as a matter of principle, be on an equal footing. Some States may argue that this is not currently the case. For instance, the right to development and the principle of permanent sovereignty over natural resources are qualified by environmental considerations, but not the other way around. ${ }^{116}$ Moreover, formulating issues as rights instead of as obligations is likely to enhance the extent to which individual States and the international community are mobilized to ensure that their rights are respected. ${ }^{117}$ This could, for example,

113 For instance, Principle 1 of the 1972 Stockholm Declaration on the Human Environment, which begins with: "Man has the fundamental right to freedom, equality and adequate conditions of life, in an environment of a quality that permits a life of dignity and well-being (...)"

114 This view is held by, inter alia, P.W. Birnie and A.E. Boyle, International Law and the Environment (Oxford University Press: 2002), at p. 90 and by P. Sands, "Protecting Future Generations. Precedents and Practicalities," in A. Agius and S. Busuttil with T. Kim and K. Yazaki (eds) Future Generations and International Law (London, Earthscan Publication: 1998), pp. 83-91, at p. 86. A number of legally binding and non-legally binding international instruments contain such a duty in their Preamble or body. See for instance Principle 3 of the 1992 Rio Declaration on Environment and Development, the Preambles to the ICRW and the CBD. For other examples see the Appendix included in Agius et al., this note, at pp. 167-176.

115 E.g., by E. Brown Weiss, In Fairness to Future Generations: International Law, Common Patrimony, and Intergenerational Equity (Tokyo, United Nations University and New York, Transnational Publishers: 1989) at p. 95 and E. Brown Weiss, "Our Rights and Obligations to Future Generations for the Environment," 84 American Journal of International Law 198-207 (1990), at p. 200.

116 E.g., Principle 3 of the Rio Declaration on Environment and Development, UNGA Resolution 1803/XVII and Art. 194 of the LOS Convention.

117 Note also that L. Gündling, "Our Responsibility to Future Generations," 84 American Journal of International Law 207-212 (1990), at p. 210 acknowledges that "rights of future generations have 'greater moral force' than mere obligations of present generations." Also, Birnie and Boyle, note 114 above, at p. 251, share the view that creating rights is not the 
encourage States individually and through RFMOs to consider the participation of non-user States, as discussed below. It goes without saying, however, that it would be better if the advocated right were complemented by more specific rights and tools. One example would be a global body with a mandate by default (i.e., in the absence of an RFMO with spatial and substantive competence), which would act as a custodian on behalf of the international community. ${ }^{118}$ Other suggestions are explored in the following subsections.

\section{Rights of Non-user States in RFMOs}

The Fish Stocks Agreement recognizes the right of States with a 'real interest' in relevant fisheries to become a member of the relevant RFMO pursuant to Article 8(3). Even though the notion of a real interest is not defined in the Fish Stocks Agreement, it may have been included to avoid a situation such as currently exists under the ICRW, which does not impose restrictions on accession or participation. ${ }^{119}$ This allows States that have no intention to engage in whaling for whatever purpose, to participate in decision-making within the IWC. This has led to a situation where qualified majority voting allows non-user States to block the lifting of the moratorium on commercial whaling even though limited whaling on certain whale populations would in principle be sustainable.

CCAMLR seems to be the only RFMO that allows States without an intention to engage in commercial fishing to become members and participate in decision-making on fisheries management and conservation. ${ }^{120}$ It should be noted, however, that CCAMLR is a unique case due to its ecosystem mandate and its incorporation in the Antarctic Treaty System. Even though CCAMLR uses consensus decision-making, non-user States do not seem to have abused their voting power to block science-based conservation measures. Other exceptions to the general rule are the Northwest Atlantic Fisheries Organization (NAFO), even though participation in the Fisheries Commission is only open to user States - or at least to States that have an intention to use - and ICCAT. ${ }^{121}$ However, the membership of ICCAT currently does not seem to include nonuser States.

cont.

same as introducing more protective rules, for the reason that rights introduce a flexibility and open-endedness that no rule can capture.

118 See also note 98 above and accompanying text.

119 See also T. Henriksen, G. Hønneland and A. Sydnes, Law and Politics in Ocean Governance. The UN Fish Stocks Agreement and Regional Fisheries Management Regimes (Martinus Nijhoff Publishers, Leiden/Boston: 2006), at p. 19. But see the complex decisions of the IWC on the reservation attached to the Icelandic instrument of accession to the ICRW.

120 See Arts. VII(2) and XXIX(1) of the CCAMLR Convention. However, such States still need to be engaged in relevant scientific research.

121 See note 55 above. See also E.J. Molenaar, "Participation, Allocation and Unregulated Fishing: The Practice of Regional Fisheries Management Organizations," 18 International Journal of Marine and Coastal Law 457-480 (2003), at p. 463. 
This practice notwithstanding, the fact remains that the notion of a real interest is not defined in the Fish Stocks Agreement and is thereby open to interpretation. In the context of NAFO, the United States has for instance argued that:

"[a] state could in principle have a real interest in a managed fishery that did not include a direct fishing interest, such as concern for a bycatch species or for the environmental effects of using a particular fishing gear."122

It is submitted that in view of the current state of marine capture fisheries worldwide, the substandard performance of many RFMOs and the need for a balance between socio-economic interests and the interests of marine biodiversity, the membership of RFMOs should seriously consider the issue of participation by non-user States. It is acknowledged, however, that the modalities of such participation should ensure that a repetition of the current situation in the IWC is avoided, for instance by expeditious compulsory dispute settlement mechanisms. ${ }^{123}$

At the same time, non-user States should exert pressure on RFMOs to enable their participation. If such pressure has an insufficient effect, they may also consider recourse to the dispute settlement procedure of the Fish Stocks Agreement. This is admittedly difficult, inter alia because the right and obligation connected to the notion of a real interest are only applicable to parties to the Fish Stocks Agreement and not to RFMOs as such. Alternatively, States whose primary motive would be the conservation of marine biodiversity may seek participation in RFMOs as a new entrant and, when allocated fishing opportunities, exercise their implicit right not to fully utilize these, as discussed in the next subsection.

\section{The Right to Under-utilize Allocations of Fishing Opportunities}

States can contribute to the conservation of marine biodiversity by exercising their implicit right not to (fully) utilize fishing opportunities allocated to them by RFMOs or other cooperative arrangements. Such a course may be taken as a consequence of assessments carried out by a government on its own initiative, with or without the involvement of stakeholders, or as a consequence of

${ }^{122}$ NAFO/GC Doc. 99/4, (1999) 'Report of the Working Group on Allocation of Fishing Rights to Contracting Parties of NAFO and Chartering of Vessels Between Contracting Parties', at Annex 6. It continues by arguing that Art. 9(2) of the Fish Stocks Agreement indicates that "it is possible to have a real interest in fisheries or in the work of a fisheries management organization or both." See also M.A. Orellana, "The Swordfish Dispute between the EU and Chile at the ITLOS and the WTO," 71 Nordic Journal of International Law 55-81 (2002), at p. 75 , who takes a similar view.

123 See in this regard the 2004 amendments to the NEAFC Convention (Report of the 23rd Annual NEAFC Meeting (2004), at pp. 37-38 and Annex K). See also T.L. McDorman, "Implementing Existing Tools: Turning Words into Action-Decision-Making Processes of Regional Fisheries Management Organisations (RFMOs)," 20 International Journal of Marine and Coastal Law 423-457 (2005), at pp. 440 and 447. 
rights given to nationals under domestic law to ensure that their government conserves marine biodiversity.

An example of the latter scenario is the right, pursuant to Section 191 of the Environment Protection and Biodiversity Conservation (EPBC) Act ${ }^{124}$ of the Commonwealth of Australia, of any person to ask the Commonwealth Minister for the Environment and Heritage to list a native species in a particular category (e.g., endangered) under the List of Threatened Species (henceforth: the List) pursuant to Section 178. This nomination is then forwarded to the Threatened Species Scientific Committee (TSSC), who, after consideration, makes recommendations to the Minister. In June 2003 the Australian Office of Humane Society International (HSI) nominated southern bluefin tuna (SBT) to be listed as endangered. Even though the species had already been listed as endangered at the state level in New South Wales, Tasmania and Victoria, ${ }^{125}$ because the individual states have in principle no competence beyond three nautical miles offshore, ${ }^{126}$ listing at the level of the Commonwealth is obviously much more important.

After the Minister twice postponed the deadline for the TSSC to submit its advice, ${ }^{127}$ the TSSC eventually recommended that SBT be listed as endangered, but went on to observe the following:

"The Committee notes the importance of Australia's leadership within [the Commission on the Conservation of Southern Bluefin Tuna (CCSBT)] to achieve long-term conservation outcomes for the SBT. In particular, the Committee recognises the need for international co-operation to address fishing impacts on the species' spawning ground. The Committee is concerned that the listing of SBT under the EPBC Act at this time may be detrimental to the survival of the species, as it may weaken Australia's ability to influence the global conservation of the species, and by implication, its conservation in Australian waters." 128

The Minister subsequently decided not to add SBT to the List and essentially reproduced the last sentence of the observation by the TSSC. ${ }^{129}$ By that time, the Minister had already, in November 2004, declared the Australian Southern Bluefin Tuna Fishery to be an approved Wildlife Trade Operation under the EPBC Act. Partly in view of the TSSC's recommendation in September 2005, HSI then appealed the November 2004 declaration before the Commonwealth's Administrative Appeals Tribunal. In April 2006, this Tribunal upheld the Minister's declaration. ${ }^{130}$

124 Cth Act No.91 of 1999, as amended (for text see <www.austlii.edu.au>).

125 Information provided by N. Beynon, HSI, Australia, May 2006. See also <www.deh.gov.au/ biodiversity/threatened/species/southern-bluefin-tuna.html $>$.

126 Cf. Section 4 of Coastal Waters (State Powers) Act (Cth Act No.75 of 1980, as amended).

${ }_{127}$ Pursuant to the Minister's powers under Section 189(4) of the EPBC Act (information provided by N. Beynon, HSI, Australia, May 2006).

${ }_{128}$ See <www.deh.gov.au/biodiversity/threatened/species/southern-bluefin-tuna.html>.

${ }^{129}$ Ibid. See also Section 186(2) of the EPBC Act.

130 HSI v. Minister for the Environment and Heritage, Case No. N2005/339, Decision of 3 April 2006; text at <www.austlii.edu.au/au/cases/cth/aat>. 


\section{Practice within RFMOs}

Coincidentally, during more or less the same period, discussions took place in the $\mathrm{CCSBT}^{131}$ on the legal nature of national SBT allocations under the CCSBT Convention ${ }^{132}$ and general international law. The discussions were sparked by the fact that South Korea had been increasingly under-utilizing its SBT allocation since 2000; according to South Korea this was due to low market prices for SBT. South Korea and possibly other Members were therefore considering the possibility of quota-trading. ${ }^{133}$ According to the external legal advice that was subsequently commissioned, quota-trading is not prohibited by the CCSBT Convention or by general international law. ${ }^{134}$ So far the CCSBT has not developed a quota-trading scheme, partly because the conservation status of SBT had (further) worsened in 2005. ${ }^{135}$ The fact that Korea had in 2005 practically not utilized its allocation at all was regarded as not unwelcome in that context. ${ }^{136}$ Further developments may have taken place at the Special Meeting of the CCSBT in July 2006, where Taiwan placed the management of overcatch and undercatch on the agenda.

Quota-trading also occurs within NAFO and ICCAT. ${ }^{137}$ Both RFMOs also allow chartering arrangements where fishing opportunities are utilized by vessels flying a flag other than that of the State to which the opportunities are allocated. 138 Moreover, the Common Fisheries Policy of the EU allows EU Member States to exchange all or part of their fishing opportunities. ${ }^{139}$

Also noteworthy is the Inter-American Tropical Tuna Commission (IATTC)'s Resolution 02-03 on Capacity of the Tuna Fleet Operating in the Eastern Pacific Ocean, which limits the purse-seine capacity to the vessels on the IATTC

${ }^{131}$ In fact, in the Extended Commission, which includes Taiwan (CCSBT-EC, or EC).

132 Convention for the Conservation of Southern Bluefin Tuna, Canberra, 10 May 1993. In force 20 May 1994, 1819 United Nations Treaty Series 360; <www.ccsbt.org>.

133 See the Report of the Extended Commission of the Tenth Annual Meeting of the CCSBT (2003), paras. 31 and 55-56 and Attachment 8-5.

134 Attachment A to Doc. CCSBT-EC/0410/16 (2004). See also Doc. CCSBT-EC/0410/Info01 (2004), which contains the legal opinion of New Zealand on this issue.

135 See the Report of the Extended Commission of the Twelfth Annual Meeting of the CCSBT (2005), paras. 106-111.

136 South Korea's reported catch for 2005 was 32 tonnes, on an allocation of 1,140 tonnes (information provided by B. Macdonald, CCSBT, June 2006).

137 See note 55 above. Cf. Doc. CCSBT-EC/0410/16 (2004), note 134 above, at Attachment A, pp. 18-19. In both cases, quota-trading requires the approval by the contracting parties. In the case of ICCAT, quota-trading is possible pursuant to ICCAT Recommendation 01-12 'Regarding the Temporary Adjustment of Quotas' (despite ICCAT Resolution 01-25 'on Criteria for the Allocation of Fishing Possibilities', which provides in para. 27: "No qualifying participant shall trade or sell its quota allocation or a part thereof"). See for instance ICCAT Resolution 03-05 'to Authorize a Temporary Catch Limit Adjustment in the South Atlantic Swordfish Fishery' (information provided by V. Restrepo, ICCAT, June 2006).

138 See Art. 15 of the NAFO Conservation and Enforcement Measures and ICCAT Recommendation $02 / 21$ on Vessel Chartering.

139 Council Regulation (EC) No. 2371/2002, of 20 December 2002, on the conservation and sustainable exploitation of fisheries resources under the Common Fisheries Policy, at Art. 20(5). 
Regional Vessel Register. Pursuant to paragraph 10 of Resolution 02-03, an exception is made for five States that are entitled to add some purse-seine vessels to the Register after 28 June 2002-the date on which the Resolution was adopted. As two of these, Costa Rica and Peru, have not yet done so, ${ }^{140}$ this amounts to de facto under-utilization. The effect of the entitlement to designate vessels as 'inactive' for at least a year ${ }^{141}$ is similar. Moreover, the Resolution allows vessels to be replaced by others, ${ }^{142}$ which implicitly allows temporary or permanent transfers of (capacity) allocations from one State to another. This thereby implicitly allows chartering as well, which is also not prohibited by other IATTC rules and procedures.

So far there seem to have been only a few instances where under-utilization of allocations has been discussed in RFMOs. Within NAFO, France (on behalf of Saint Pierre and Miquelon) was instrumental in pressing for a chartering arrangement. Both Canada and Japan took the view that the purpose of chartering should not be to fill a gap in fishing capacity and thereby in fact advocated a 'use-it-or-lose-it' approach. ${ }^{143}$ However, the fact that a chartering arrangement was in the end approved implies that this approach did not find sufficient support. Another instance where under-utilization was discussed in RFMOs involved South Korea in the context of the CCSBT. Here too, a 'useit-or-lose-it' approach was not adopted. Finally, within ICCAT it is established practice to allow States to carry over under-utilizations (underages) from one year to another, with some limitations. ${ }^{144}$

Under-utilization of allocations also occurs within the EU. One example is - or, possibly, has been-Germany's under-utilization of its allocation for Redfish (Sebastes spp.) in the maritime zones of Greenland, ${ }^{145}$ presumably for lack of interest and lack of opportunities to swap this allocation with other allocations. Despite objections from other EU Member States, Germany was able to continue its under-utilization by relying on the principle of relative stability, which essentially freezes an agreed allocation key for certain species in certain management areas. ${ }^{146}$ Moreover, the fact that EU Member States are

${ }^{140}$ Information provided by B. Hallman, IATTC, 13 June 2006.

${ }^{141}$ Cf. para. 9.

142 Cf. paras. 7-9.

143 See Section 9 and Annex 3 to NAFO/GC Doc 99/4, note 122 above.

144 The point of departure of the practice is laid down in ICCAT Recommendation 00-14 'Regarding Compliance with Management Measures which Define Quotas and/or Catch Limits'. For examples of the practice see, e.g., ICCAT Recommendations 02-08 (para. 4), 02-02 (para. 5), 02-01 (para. 4), 01-13 and 98-07 (para. 6). Some limits to the practice are laid down in, e.g., ICCAT Recommendations 04-01 (para. 4(b)) and 03-06 (para. 6) and ICCAT Resolution 03-05, note 137 above.

145 Council Regulation (EC) No. 51/2006 of 22 December 2005 fixing for 2006 the fishing opportunities and associated conditions for certain fish stocks and groups of fish stocks, applicable in Community waters and, for Community vessels, in waters where catch limitations are required $(O J 2006, \mathrm{~L} 16 / 1)$, at p. 86.

146 Cf. Art. 20(1) of Council Regulation (EC) No. 2371/2002, note 139 above, and the settled jurisprudence of the European Court of Justice. 
allowed to transfer $10 \%$ of some allocations from one year to the next, ${ }^{147}$ also implicitly recognizes the right to under-utilize allocations. In the context of fisheries access agreements between the EU and third States, however, provisions usually stipulate that under-utilization of allocations entitles other EU Member States to request an allocation. ${ }^{148}$ There have nevertheless been instances in which the EC Commission has rejected such requests for conservation reasons. ${ }^{149}$

The practice within NAFO, CCSBT, IATTC, ICCAT and the EU shows that under-utilization occurs regularly and that a 'use-it-or-lose-it' approach has so far never been rigidly pursued. However, the instances of under-utilization were practically all motivated by reasons of fishing capacity or economic viability and not for the conservation of marine biodiversity. The only exception is some practice of the EC Commission, but the context and legal regime under which this occurred is very different from the other examples.

\section{Relevant Rights and Obligations under General International Law}

Under general international law coastal States have, pursuant to their sovereignty and sovereign rights over marine living resources in their maritime zones, the right not to engage in fishing in order to conserve marine biodiversity. In fact, pursuant to Article 61 of the LOS Convention, coastal States are obliged to avoid over-exploitation not only of target species but also of associated and dependent species, as well as to take account of relevant environmental factors, which could be regarded as a reference to the broader marine environment. In addition, Part XII of the LOS Convention establishes a general duty for States to protect and preserve the marine environment, with special reference to "rare or fragile ecosystems as well as the habitat of depleted, threatened or endangered species and other forms of marine life." 150 Finally, in the scenario under investigation, the obligations under Article 62 of the LOS Convention to promote the objective of optimum utilization and to give other States access to the surplus of the TAC are not applicable, as they are "without prejudice to article 61." While high seas fishing States are not bound to the objective of optimum utilization, they have a similar obligation to conserve marine biodiversity and thereby a similar implicit right not to engage in high seas fishing for that purpose. ${ }^{151}$

${ }^{147}$ Cf. Art. 4(2) of Council Regulation (EC) No. 847/96, of 6 May 1996, introducing additional conditions for year-to-year management of TACs and quotas (OJ 1996, L 115/3).

148 See, for instance, Art. 2 of Council Regulation (EC) No. 764/2006, of 22 May 2006, on the conclusion of the Fisheries Partnership Agreement between the European Community and the Kingdom of Morocco (OJ 2006, L 141/1).

149 For instance in 2004-2005 when the EC Commission decided, in view of the conservation status of octopus in the waters of Mauritania, not to utilize 5 licenses that were still available under the fisheries access agreement with Mauritania (information provided by H. Koster, EC Commission, 9 June 2006).

150 Art. 194(5).

151 See Arts. 116-119 of the LOS Convention. 
For States that are not just parties to the LOS Convention but also to the $\mathrm{CBD}$, which currently amounts to almost the entire international community of States, the obligations of the LOS Convention are complemented and deepened by the obligations under the CBD to conserve marine biodiversity. Similarly, for States that are not just parties to the LOS Convention but also to the Fish Stocks Agreement, the latter's obligations with regard to the precautionary approach and various ecosystem considerations complement the more general and less specific obligations for straddling and highly migratory fish stocks laid down in the LOS Convention.

\section{Responsible Action in RFMOs}

More complicated is the situation where States that cooperate on the conservation and management of transboundary or discrete high seas fish stocks have agreed to allocate fishing opportunities to avoid over-exploitation. In such situations the cooperative arrangement's objectives and its decision-making procedures are all relevant for the scenario under investigation.

Conservation of marine biodiversity can be achieved in various ways, for instance by prohibiting certain fishing practices or by prohibiting targeted fishing for certain species. In many cases, however, a lower TAC for a particular species will be sufficient to conserve marine biodiversity. Assuming that agreement on a lower TAC within a cooperative arrangement would equitably spread the burden of conservation among the participants, this would be the preferred solution for most participants. This is so because apart from the special case of CCAMLR, participants in cooperative arrangements also do this for socio-economic reasons. However, the necessary majority for a lower TAC may not be obtainable. Participants with biodiversity concerns are then faced with several options. They could opt for a pragmatic rather than a fundamental approach by not opposing a higher TAC and subsequently under-utilizing their allocations. This would also avoid, at least for some time, anticipatory proposals for even higher TACs to compensate for under-utilization. Those that prefer to emphasize that this is a matter of principle, however, may use their right to opt out, if available. However, there may also be a blocking minority against alternatives for the lower TAC. In the case of decisionmaking on the basis of consensus or unanimity, this block could be achieved by a single participant.

In the last scenario, the effect of a blocking minority could be to have no fishing opportunities allocated at all, with all the risks that an unregulated fishery would have for the species and the broader marine ecosystem, as well as for the credibility and legitimacy of the cooperative arrangement. It is submitted that, faced with such risks, participants would act more responsibly by not blocking decision-making and subsequently by not fully, or not at all, utilizing their allocations. Other participants would then be bound to the agreed (higher) TAC and the allocations of fishing opportunities. A participant that 
utilizes another participant's allocation would exceed its own allocation, and thereby violate applicable obligations under the cooperative arrangement and possibly even incur a 'pay-back' obligation. It is recognized, however, that intentional under-utilization may not be an option for EU Member States due to entitlements to fishing opportunities by EU nationals pursuant to EU law.

Such action would not necessarily be inconsistent with the objectives of the cooperative arrangement. Most RFMOs have a dual objective of conservation and (rational) utilization, while some - such as the CCSBT-are also bound to the objective of optimum utilization. As in the LOS Convention and Fish Stocks Agreement, however, the objective of optimum utilization is usually dependent on, or subsidiary to, the objective of conservation or long-term sustainability. In cases where lower TACs cannot be agreed, under-utilization of allocations may be justified by the conservation objective.

As the objective of some cooperative arrangements is limited to target species, ${ }^{152}$ it would, strictly speaking, not be possible to under-utilize allocations for the purpose of conserving other forms of marine biodiversity. However, as the constitutive instruments of most cooperative arrangements usually contain provisions that allow States-parties to fulfill their obligations under other treaties or international law in general, ${ }^{153}$ it is arguable that under-utilization for other purposes would still be possible.

Whether a State is entitled to under-utilize its allocation for the purpose of conserving marine biodiversity depends largely on its scientific basis and the application of the precautionary approach. The principle of good faith and the prohibition of abuse of rights, both of which are part of general international law, are also relevant in assessing the legality of such an entitlement. Legality is more likely to exist in scenarios where a management body deviates from the advice by a scientific body, where the advice by the scientific body was not agreed on by consensus or where the management and/or the scientific body have not, or incorrectly, applied the precautionary approach. Provided it is science-based and proceeds from a justifiable application of the precautionary approach, under-utilization of allocations will strengthen a State's credibility as a responsible fisheries management authority, rather than undermine it. ${ }^{154}$ This would be different if under- or non-utilization were motivated by ethical or cultural considerations, which would bring into question a State's allegiance to the utilization objective of cooperative arrangements.

Finally, it should be recognized that the ability to under-utilize for conservation reasons depends first of all on the applicable decision-making procedures. In the case of consensus decision-making, even a single participant may block anticipatory proposals for higher TACs to compensate for under-utilization or

152 See, for example, Arts. I(4) and II(1) of the NAFO Convention.

153 See, for example, Art. 4 of the CCSBT Convention.

154 For the latter view, see the 2006 Decision by the AAT, note 130 above, at para. 56 . 
proposals that pursue a use-it-or-lose-it approach. In cases where participants with biodiversity concerns do not have a blocking minority, the remedies are more limited, but not absent. One of these is to challenge the legality of the majority's behavior in the course of a dispute settlement procedure, where available.

Coastal State Jurisdiction over the (Outer) Continental Shelf

Article 77(1) of the LOS Convention recognizes a coastal State's sovereign rights over its continental shelf "for the purpose of exploring it and exploiting its natural resources." These natural resources consist of the non-living resources of the sea-bed and subsoil, together with living organisms belonging to sedentary species. ${ }^{155}$ It is submitted elsewhere that sedentary species can be regarded as including species such as clams, pearl shells, abalone, corals, sponges and other benthic communities. ${ }^{156}$

As regards the rights and obligations of coastal States over their outer continental shelves, there are two issues where reform seems particularly necessary. The first relates to the fact that the LOS Convention currently does not clearly require coastal States to conserve sedentary species. The obligations in relation to ecosystems and habitats under Article 194(5) lack clarity as well and, in any event, do not relate to target species.

The second concerns the lack of guidance offered by the LOS Convention as to how the justifiability of interference by coastal States with high seas fishing above outer continental shelves should be assessed. Some States take the view that:

"in conformity with the [LOS Convention], the coastal State was fully entitled to adopt any conservation and management measures it deemed necessary to protect its sedentary species on the continental shelf. Those may include the possibility of imposing restrictive measures on fishing activities in the high seas over its continental shelf, including on fishing practices that were deemed to have a negative impact on sedentary species." 157

However, the fact that only "some" States take this view means that others do not or have not determined a position yet. As far as could be ascertained, no coastal States have yet imposed such measures. ${ }^{158}$ Also, the cited view does not take account of the relevance of the presence of RFMOs or Arrangements

155 Art. 77(4) of the LOS Convention.

156 Molenaar, note 47 above, at pp. 557-563. See also L.A. Kimball, "Deep-Sea Fisheries of the High Seas: The Management Impasse," 19 International Journal of Marine and Coastal Law 259-287 (2004), at pp. 275-277, 279-281 and 286; and Hayashi, note 70 above, at p. 293.

157 See the Report of the Ad Hoc Open-ended Informal Working Group established by the UNGA to study issues relating to the conservation and sustainable use of marine biological diversity beyond areas of national jurisdiction (UN Doc. A/61/65, of 20 March 2006), at p. 7, para. 22 .

158 It is worth noting, however, that by 2020 New Zealand intends to have established some marine protected areas beyond its EEZ to protect benthic communities (cf. UN Doc. A/61/ 154 , note 5 above, at p. 23, para. 93). But this may not necessarily be done unilaterally. 
that have spatial competence over these outer continental shelves and their regulation of fisheries affecting sedentary species of outer continental shelves. Finally, so far no coastal States have concluded the LOS Convention's procedure involving the Commission on the Limits of the Continental Shelf (CLCS) for establishing the outer limits of their outer continental shelf. The precise spatial scope of their rights is therefore unclear as well. In conclusion, there seems to be a need for clarification of the relationship between the sovereign rights of coastal States over sedentary species on their outer continental shelves, the freedom of high seas fishing, the presence of and regulation by RFMOs or Arrangements and the consequences of not having established final and binding outer limits.

While clarification on the second issue could be provided in the course of an international dispute settlement procedure, this would not resolve the first issue. The international community may in any event prefer not to wait for such a procedure and commence negotiations towards a legally binding instrument that incorporates clarification on both issues.

As regards the form of such an instrument, an Implementation Agreement to the LOS Convention seems to be the most likely. The issue of the outer continental shelf may be the only issue addressed by this Implementation Agreement or it may be dealt with as part of a package. If the international community decides to resolve the gap identified in subsection 4.1 in relation to fish stocks discrete to ABNJ - therefore including sedentary species - it would seem logical to also incorporate clarification on the two issues discussed in this subsection.

Port State Jurisdiction: Optimizing Use, Broadening Rights and Striving towards Mandatory and Global Coverage

By complementing the flag State's primary responsibility over ships flying its flag, port States can make an important contribution to ensuring compliance with international regulatory efforts. ${ }^{159}$ These efforts include combating IUU fishing and thereby assisting the conservation of biodiversity in ABNJ.

Under general international law, vessels have no right of access to foreign ports and port States have broad powers to prescribe and enforce. The legality or justifiability of extra-territorial port State jurisdiction-meaning jurisdiction over behavior occurring beyond the port State's own maritime zones-depends not only on a sufficient jurisdictional basis but also on the type of enforcement action taken. ${ }^{160}$ This ranges from less onerous enforcement measuressuch as denial of entry into port or the use of port services - to more onerous enforcement measures - such as imposing monetary penalties or confiscating

159 See UNGA Resolution 60/30, of 29 November 2005, para. 47 and UNGA Resolution 60/31, of 29 November 2005 , paras. 36 and 42 .

${ }^{160}$ For a general discussion see E.J. Molenaar, "Port State Jurisdiction: Towards Mandatory and Comprehensive Use," in D. Freestone, R. Barnes and D. Ong (eds) The Law of the Sea: Progress and Prospects (Oxford University Press: 2006), pp. 192-209. 
catch. A port State's residual jurisdiction-meaning its competence to prescribe more stringent standards than those agreed to within competent international organizations such as IMO - is not affected by adherence to IMO instruments as such. The implications of international trade law with regard to a port State's residual jurisdiction are nevertheless unclear.

It is submitted that current general international law entitles port States to exercise extra-territorial jurisdiction over IUU fishing activities on the high seas. ${ }^{161}$ However, state practice indicates that only the less onerous enforcement measures are imposed and thereby suggests that jurisdiction is not unlimited. No support therefore exists in state practice for the view that Article 25(2) of the LOS Convention and Article 23(4) of the Fish Stocks Agreement confirm unlimited port State jurisdiction and that a jurisdictional basis similar to Article 218 of the LOS Convention - which gives port States the right to institute proceedings with regard to illegal discharges beyond its own maritime zoneswould not be necessary to impose more onerous measures. ${ }^{162}$

Until such time as the international legal framework gives port States in the sphere of marine capture fisheries additional enforcement powers similar to Article 218 of the LOS Convention, States are encouraged to make "the fullest possible use of its jurisdiction under international law in furtherance of not just [their] own rights and interests but also those of the international community." 163 Accordingly, a 'responsible port State' should, balanced by appropriate safeguards, optimize the use of port State jurisdiction, for instance by using criminal or administrative law to lay charges such as furnishing false information, by pursuing Lacey Act-type approaches, or by taking action against stateless vessels. ${ }^{164}$ In addition, it should use the opportunities that integrated in-port enforcement offers for combating IUU fishing, for instance, by subjecting suspected vessels to enforcement for purposes other than conservation and management of marine living resources.

The effectiveness of port State jurisdiction as a tool to combat IUU fishing and thereby to conserve biodiversity in ABNJ is currently significantly diminished by the fact that the objective of mandatory and global coverage of port State measures still lies far ahead. A shift from optional to mandatory port State jurisdiction nevertheless seems to be unavoidable. Awareness that the interests of the international community are not only undermined by free riders in their capacity as flag States, but also in their capacity as port States

${ }^{161}$ For an understanding of the components of IUU fishing see paras. 3.1-3.4 of the IPOA on IUU Fishing (International Plan of Action to Prevent, Deter and Eliminate Illegal Unreported and Unregulated Fishing. Adopted by consensus by FAO's Committee on Fisheries on 2 March 2001 and endorsed by the FAO Council on 23 June 2001; text available at $<$ www.fao.org/fi>).

162 Cf. Molenaar, note 160 above, at p. 202.

163 Closing the Net: Stopping Illegal Fishing on the High Seas, Final Report of the Ministerially-led Task Force on IUU Fishing on the High Seas (2006; text at <www.high-seas.org $>$ ), at p. 78.

${ }^{164}$ Cf. Closing the Net, note 163 above, at p. 78 and Molenaar, note 160 above, at p. 204. 
through so-called 'ports of convenience', is expected to spread due to current and future concerns, including those on international terrorism. The FAO Port State Model Scheme ${ }^{165}$ aims to contribute to the creation of a global network of regional port State jurisdiction for the purpose of marine capture fisheries and offers guidance and opportunities for harmonization in this respect. So far, there have been only a few efforts to implement the FAO Scheme by RFMOs. ${ }^{166}$

Most recently, the FSA Review Conference recommended to

“initiate, as soon as possible, a process within FAO to develop, as appropriate, a legally binding instrument on minimum standards for port State measures, building on the [FAO Port State Model Scheme] and the [IPOA on IUU Fishing]."167, 168

This Norwegian proposal was explicitly supported by many delegations, including the EU and New Zealand, with Japan cautiously indicating a willingness to consider it. ${ }^{169}$ If such a process will indeed be initiated, it will probably be decided at the 27th Session of COFI ${ }^{170}$ in March 2007. This recommendation by the FSA Review Conference implicitly reflects broad agreement that the FAO Port State Model Scheme-if not substantively, then at least as regards its non-legally binding status - and/or the extent to and the way in which it has so far been implemented, is not adequate to achieve the aforementioned objectives.

The need for a global approach to marine capture fisheries seems indeed more pertinent in comparison with the regulation of merchant shipping for the protection and preservation of the marine environment. While barring substandard ships at the regional level reduces the risk to the regional marine environment (but probably increases the risk in other regions), the increasing practice of transshipment of catch at sea means that fish caught in one region can easily be landed anywhere on the globe. This practice also underscores the need to target not just fishing vessels with fish (products) on board, but also other vessels carrying fish (products), as well as fishing vessels that have no fish (products) on board. ${ }^{171}$

${ }^{165}$ Model Scheme on Port State Measures to Combat Illegal, Unreported and Unregulated Fishing (Annex E to the 'Report of the Technical Consultation to Review Port State Measures to Combat Illegal, Unreported and Unregulated Fishing. Rome, 31 August-2 September 2004' (FAO Fisheries Report. No. 759 (Rome, FAO: 2004)), endorsed by COFI at its Twenty-Sixth Session in March 2005 ('Report of the twenty-sixth session of the Committee on Fisheries. Rome, 7-11 March 2005' (FAO Fisheries Reports No. R780: 2005), at para. 25).

${ }^{166}$ For instance the adoption of SEAFC Conservation Measure 02/05 'on Interim Port State Measures', which uses Annexes B and C of the FAO Port State Model Scheme.

167 See note 161 above.

${ }_{168}$ Cf. Doc. A/CONF.210/2006/15, note 8 above, at p. 39, para. 43(d).

169 Earth Negotiations Bulletin, Vol. 7, No 59, at pp. 1-2 (available at <www.iisd.ca>).

170 See note 13 above.

171 See, inter alia, the discussion during the 24th Annual CCAMLR Meeting (2005), where Argentina opposed several amendments to CCAMLR Conservation Measure 10-03 (2005) 'Port inspections of vessels carrying toothfish', which would, inter alia, have required inspections 
The words "minimum standards for port State measures" suggest that the negotiation process will have a modest objective, perhaps aimed at little more than incorporating the substance of the FAO Port State Model Scheme and the relevant parts of the IPOA on IUU Fishing in a legally binding instrument. The cited words thereby imply that a more ambitious undertaking aimed at a comprehensive package of rights and obligations of port States in relation to marine capture fisheries is not expected to secure the necessary support.

The challenge will be to ensure that, compared with the instruments on which it builds, the envisaged instrument has clear added value. While rights of access to ports per se may be difficult to accept for coastal States with fleets that now have a competitive advantage due to proximity to high seas fishing grounds, they may be acceptable as part of an overall package. Possible other elements of the package are obligations with regard to inspection, denial of landing and use of port services, safeguards for flag States, assistance to developing States (possibly through a dedicated fund), compulsory dispute settlement, and a port State's right to institute proceedings for IUU fishing activities on the high seas. The latter right would include a right to confiscate IUU catch and to impose monetary penalties. In order to avoid abuse of this right, but without at the same time removing the port State's incentive to enforce, it could be stipulated that part of the proceeds of the sale of the IUU catch and/or the monetary penalty are to be deposited in a fund. Account could thereby be taken of the experience of CCAMLR, where Contracting Parties that have seized or confiscated toothfish (Dissostichus spp.) - presumably in accordance with current international law-may transfer all or part of the proceeds of the sale to the CDS Fund. ${ }^{172}$

Non-flag States and the Genuine Link

While the need to combat IUU fishing is widely recognized, it is submitted that clarification of the concept of the genuine link ${ }^{173}$ would only be helpful if it is focused on, or explicitly linked to, clarifying the consequences of the absence of a genuine link between a vessel and its flag State. Or, in other words, if it is focused on clarifying the rights of non-flag States over such a

cont.

of all vessels carrying toothfish (cf. the Report of the 24th Annual CCAMLR Meeting (2005) (Doc. CCAMLR-XXIV), at paras. 11.16-11.17, 16.9 and 17.3-17.4

172 Cf. para. 18 of CCAMLR Conservation Measure 10-05 (2005) 'Catch Documentation Scheme [CDS] for Dissostichus spp.'. Annex B contains the procedure for the operation of the CDS Fund. In 2001 the United Kingdom deposited part (AUD\$ 284,789.78) of the proceeds of the sale of toothfish caught within the CCAMLR Convention Area without an authorization by one of its own vessels, the Mila, in the CDS (cf. Report of the 20th Annual CCAMLR Meeting (2001) (Doc. CCAMLR-XX), at p. 136).

173 See Art. 91(1) of the LOS Convention and Doc. A/CONF.210/2006/15, note 8 above, at p. 17, para. 81, p. 22, para. 101 and p. 37, para. 32(h). For a recent analysis of the concept see D. Anderson, "Freedoms of the High Seas in the Modern Law of the Sea," in Freestone et al., note 160 above, pp. 327-346, at pp. 332-340. 
vessel. Until such a reform has been completed, States, whether individually or cooperatively, may be willing to seek, through state practice, clarification of these issues and of the basic international flag State obligations to exercise effective jurisdiction and control over their ships and to cooperate in the management and conservation of transboundary and discrete high seas fish stocks. One option would be to take enforcement action in the high seas parts of an RFMO against unregulated fishing activities carried out under the flag of States that are blatantly failing to cooperate with that RFMO. It is submitted that the absence of a genuine link and/or the failure to cooperate is particularly obvious for violations of fisheries regulations in (integrated) MPAs in ABNJ. Such a view may be corroborated - or not-in the course of an international dispute settlement procedure instituted in the aftermath of such enforcement action. The considerable costs of such procedures may already be sufficient reason for States to cooperate, inter alia, by pooling resources.

\section{Conclusions}

The current international legal framework relating to the conservation and sustainable use of marine biodiversity in ABNJ consists of a multitude of global, regional and bilateral legally binding and non-legally binding instruments and acts by intergovernmental organizations (IOs). As a whole, the framework is highly sectoralized and decentralized and suffers as a consequence not only from spatial and substantive gaps, but also from actual and potential overlaps.

The need for reform of this framework should be assessed in light of, inter alia, the threats to marine biodiversity in ABNJ. Once the need for reform has indeed been ascertained, attention shifts to the form and level of reform. This phase includes, inter alia, a cost-benefit analysis of various options, partly in light of the severity of the threat to marine biodiversity and the urgency of reform. The outcome of this phase may well be that reform should not be undertaken.

Spatial and substantive sectoral gaps in the current legal framework exist, inter alia, in areas beyond national jurisdiction (ABNJ) that are not covered by regional fisheries management organizations (RFMOs) at all or only by RFMOs with narrow mandates or substandard performance. These gaps are currently being addressed. Many ABNJ are also not covered by regional marine environmental protection instruments and bodies at all or, possibly, merely by instruments and bodies with inadequate mandates and performance. Also lacking are regulatory frameworks with competent IOs for certain human activities - such as marine scientific research-that are carried out in ABNJ. There may well be a need for reform of the international legal framework on these aspects.

In view of the decentralized nature of international law and the absence of hierarchy among its forms/manifestations as well as its law-making processes, the form and level of a proposed reform should minimize competition or overlap 
with existing legal regimes. This is a particularly important consideration in light of the identified need to move from sectoral governance towards integrated ecosystem-based oceans management and the support for integrated marine protected areas (MPAs) in ABNJ.

The present article elaborated on the need for reform in relation to some selected substantive issues, namely discrete high seas fish stocks, deep-sea species and fisheries, integrated MPAs in ABNJ, and existing and new rights to conserve marine biodiversity. As regards the last issue, it notes that, at a high level, reform is guided by the universal but flexible goal of sustainable development and thereby pursues an equitable balance between socio-economic interests and the interests of marine biodiversity of present and future generations. Arguably, another necessary balance that such reform should strike is one between rights and obligations of States to conserve marine biodiversity. In view of the current rate of loss of marine biodiversity, reform should not just be limited to the traditional approach of strengthening, deepening and broadening obligations, but should be balanced with optimizing the use of existing rights and/or granting new rights to ensure that the overarching balance is achieved.

Examples of existing rights that could be more optimally used and new rights that could be granted are (a) a general but explicit right for States to marine biodiversity, (b) rights of non-user States in RFMOs, (c) rights of members of RFMOs to under-utilize their allocations of fishing opportunities, (d) rights of coastal States over their (outer) continental shelves, (e) rights of port States over IUU fishing on the high seas and (f) rights of non-flag States in the absence of a genuine link and a blatant failure to cooperate in the management and conservation of transboundary and discrete high seas fish stocks. 